\title{
Gerakan Islam Transnasional: Sebuah Nomenklatur, Sejarah dan Pengaruhnya di Indonesia
}

\author{
Aksa \\ Staf Pengajar Program Konsentrasi Pendidikan Sejarah Universitas Mulawarman \\ aksa131288@gmail.com
}

\begin{abstract}
Transnational Islamic movement is a terminology that belongs in the new academic study. The term has become a ' nomenclature 'is generally understood as an ideology that crosses state boundaries (nation state). The emergence of transnational Islamic movement's lively lately is part of an Islamic revival and renewal of an era that grew in the Middle East since the $18^{\text {th }}$ century. The post-war collapse of the Caliphate based in Ottoman Turkey in 1924, the movement has found the right momentum by forming new forces in conducting resistance against colonialism and imperialism of the West. Presence of transnational Islamic movement in Indonesia is part of the revivalism Islamic movement in the Middle East that directly make effect against the pattern of Islam in Indonesia. Transmission lines the ideas of this movement through the social movements, education and publications.
\end{abstract}

Keywords: Islamic movement, Transnational Islam, Indonesia.

\begin{abstract}
ABSTRAK
Gerakan Islam transnasional adalah sebuah terminologi yang tergolong baru dalam kajian akademik. Istilah tersebut telah menjadi sebuah 'nomenklatur' yang secara umum dipahami sebagai sebuah ideologi yang melintasi batas kenegaraan (nation state). Munculnya gerakan Islam transnasional yang marak akhir-akhir ini adalah bagian dari era kebangkitan dan pembaharuan Islam yang berkembang di Timur Tengah sejak abad ke-18. Pasca runtuhnya kekhalifahan yang berpusat di Turki Usmani pada 1924, gerakan tersebut telah menemukan momentum yang tepat dengan membentuk kekuatan-kekuatan baru dalam melakukan perlawanan terhadap kolonialisme dan imperialisme Barat. Hadirnya gerakan Islam transnasional di Indonesia adalah bagian dari gerakan revivalisme Islam di Timur Tengah yang berpengaruh langsung terhadap corak keislaman di Indonesia. Jalur transmisi ide-ide gerakan ini melalui jalur gerakan sosial, pendidikan serta publikasi.
\end{abstract}

Kata Kunci: Gerakan Islam, Islam Transnasional, Indonesia.

\section{PENDAHULUAN}

Islam sebagai sebuah agama telah diyakini oleh penganutnya sebagai ajaran yang terakhir dan dinyatakan final sampai akhir jaman. Meskipun demikian, bukan berarti ajaran yang dianut oleh para penganutnya selalu sama dalam memahami, mengkaji dan mengamalkan teks-teks yang ada dalam kitab suci Al-
Qur'an. Dalam pengalaman sejarah, fenomena keberislaman individu atau kelompok dalam bermasyarakat menunjukan bahwa Islam hanya satu yang diturunkan oleh Tuhan, tetapi dalam prakteknya di tengah kehidupan sosial telah melahirkan multiinterpretasi terhadap Islam. Dengan kata lain, Islam bagi kaum muslimin memang ada satu 
yang diwahyukan dan dimandatkan Tuhan, tetapi terdapat banyak penafsiran tentang Islam (Esposito, 2004: xv-xvi).

Banyaknya penafsiran tersebut, berimplikasi pada munculnya banyak perubahan dalam Islam seperti paham, keyakinan, aliran dan gerakan-gerakan keagamaan. Perubahan tersebut disebabkan karena adanya perbedaan interpretasi dan cara pandang dalam memahami situasi dan kondisi yang terus berubah sebagai akibat dari berkembangnya ilmu pengetahuan dan teknologi, walaupun kitab suci yang dijadikan pedoman hanya satu dan tidak pernah berubah. Dalam perkembangannya, di dunia Islam muncul gerakan-gerakan keislaman yang mempunyai ciri khas yang berbeda dengan Islam yang dominan, dipercayai dan diyakini oleh umat Islam secara umum.

Fenomena keberagaman gerakan sosial Islam di era kontemporer telah mewarnai berbagai aktivitas dan dakwah dalam pengembangan Islam. Salah satu yang menarik dalam kajian akademik akhir-akhir ini yaitu dengan munculnya gerakan Islam global atau disebut dengan "Gerakan Islam Transnasional". Gerakan ini umumnya memiliki ciri ideologi yang tidak lagi bertumpu pada konsep kenegaraan (nation-state), melainkan cenderung fokus pada konsep ideologi untuk kemaslahatan umat.
Gerakan ini didominasi oleh corak pemikiran normatif, skripturalis, fundamentalis yang terkadang secara parsial mengadaptasi gagasan dan instrumen modern.

Beberapa organisasi Islam yang termasuk dalam kategori gerakan Islam transnasional dan kaki tangannya yang ada di Indonesia antara lain: Ikhwanul Muslimin di Mesir, Hizbut Tahrir di Lebanon, Wahabiyah di Arab Saudi, Jama'ah Islamiyah di Pakistan, Gerakan Salafi Jihadis di Irak dan Afganistan, serta Syi'ah yang berpusat di Iran. Gerakan Islam transnasional telah membawa pengaruh yang cukup kuat di Indonesia sampai saat ini. Spektrum Gerakan dari organisasi ini adalah sama-sama mengedepankan formalisasi syariat dan menegakkan khilafah dalam dunia Islam dengan scope gerakan dan metode perjuangan yang berbeda-beda. Gerakan Islam tersebut merupakan representasi gerakan baru Islam di Indonesia yang mempunyai jaringan dan anggota lintasnegara atau sering disebut sebagai "Gerakan Islam Transnasional".

\section{GERAKAN ISLAM TRANSNASIONAL SEBUAH NOMENKLATUR}

Gerakan Islam transnasional adalah sebuah istilah yang ditujukan kepada organisasi Islam yang bergerak lintas negara, dimana pergerakannya melewati batas-batas teritorial setiap negara. 
Dalam upaya menjelaskan terminologi Islam transnasional atau "transnasionalisme Islam" (Islamic transnationalism) sebagai sebuah nomenklatur, Masdar Hilmy meminjam pengertian yang diungkapkan oleh J. R Bowen yang mencakup tiga hal yaitu: (1) pergerakan demografis, (2) lembaga keagamaan transnasional, dan (3) perpindahan gagasan atau ide (Hilmy, 2011: 2 ).

Pengertian pertama bermakna bahwa transnasionalisme Islam berarti pergerakan Islam lintas negara. Pengertian kedua bermakna perangkat kelembagaan yang memiliki jejaring internasional. Pengertian ketiga adalah perpindahan ide atau gagasan dari individu atau kelompok satu ke individu atau kelompok yang lain, serta dari negara satu ke negara yang lain. Apabila terminologi Islam transnasional dikategorikan dalam arti demikian, maka terdapat kesamaan persepsi secara umum bahwa gerakan Islam transnasional atau transnasionalisme Islam adalah sebuah gerakan Islam yang melintasi wilayah teritorial/batas negara tertentu. Gerakan organisasi ini berorientasi pada agenda penyatuan umat Islam di seluruh dunia, dimana ideologi keislamannya didominasi oleh pemikiran skripturalis, tekstual, normatif, radikal, fundamental, dimana gagasannya berbeda dengan konsep negara bangsa (nation-state).

Ikhwanul Muslimin adalah kelompok gerakan Islam yang didirikan oleh Hasan Al-Banna. Kelompok gerakan yang memegang kekuasaan di Mesir ini ingin mengembalikan kekuatan Islam sebagai basis politik dan keluar dari konsep demokrasi dan hegemoni Barat yang dianggap mencengkeram umat Islam. Selain itu, peran yang paling menonjol adalah salafisme yang dimainkan oleh Arab Saudi dalam mempromosikan agenda globalnya. Salafisme mampu mengatasi apa yang disebut oleh Roy sebagai upaya "deteritorialisasi" Islam secara lebih baik daripada beberapa bentuk keberagamaan Islam lainnya (Roy, 2004: 18).

Globalisasi mengakibatkan Islam saat ini kurang dinisbahkan kepada kawasan atau wilayah tertentu. Hal ini disebabkan karena sebagian besar umat Muslim di dunia hidup di luar negara yang secara tradisional masih menganut agama Islam. Roy mengemukakan bahwa deteritorialisasi bisa juga dialami oleh Muslim yang tidak melakukan migrasi. Dengan kata lain, gejala "Westernisasi" menyebabkan masyarakat sendiri tidak menyadari bahwa mereka berada dalam kelompok minoritas (Roy, 2004: 19).

Deteritorialisasi yang dimaksudkan juga memiliki kesamaan dengan pandangan transnasionalisme, dimana 
sebuah gerakan bekerja melalui ideologi dan jejaring yang sangat luas dan melintasi batas teritorial negara tertentu. Target utama dari gerakan deteritorialisasi ini adalah untuk mengubah budaya asli negara muslim setempat dengan pandangan baru yang dianggap dimiliki oleh Islam murni. Dengan demikian, umat Islam yang berbeda dengan pandangan kelompok gerakan ini dianggap salah dan tidak menerima akulturasi kebudayaan Islam dengan kebudayaan lokal sebagai kearifan lokal yang dimiliki oleh masyarakat yang berpenduduk Islam di daerah dan negara tertentu.

Terdapat berbagai istilah yang dipakai oleh para sarjana dan pengamat untuk mengidentifikasi dan menjelaskan fenomena kebangkitan Islam di dunia Muslim, antara lain: radikalisme, revivalisme, skripturalisme, Islam politik (political Islam), ekstrimisme, dan fundamentalisme. Namun, istilah fundamentalisme nampaknya lebih umum dipakai oleh para sarjana, pengamat maupun akademisi. Akan tetapi, berbagai istilah tersebut masih diperdebatkan dan dipersoalkan, terutama istilah fundamentalisme yang dianggap mengandung makna negatif terhadap Islam.

Esposito merupakan salah satu kalangan sarjana barat yang mengemukakan bahwa istilah fundamentalisme setidaknya digunakan dalam tiga pengertian. Pertama, mereka yang berusaha menyerukan panggilan untuk kembali pada kepercayaan dasar atau pondasi agama bisa disebut kelompok fundamentalis. Dalam konteks masyarakat Islam, usaha kembali kepada Al-Quran dan Sunnah Rasul adalah sebuah model hidup yang normatif. Kedua, pemahaman dan persepsi tentang fundamentalisme sangat dipengaruhi oleh tradisi Protestanisme Amerika. Fundamentalisme adalah gerakan Protestanisme abad ke-20 yang menekankan penafsiran Injil secara literal sebagai sesuatu yang fundamental bagi kehidupan dan ajaran Kristen. Ketiga, istilah fundamentalisme sering kali dikaitkan dengan aktivitas politik, ekstrimisme, fanatisme, terorisme, dan anti-Amerikanisme. Oleh karena itu, istilah tersebut oleh Esposito dianggap terlalu bermuatan presuposisi kristen dan stereotip Barat, serta mengisyaratkan ancaman monolitik yang tidak eksis (Esposito, 1994: 17-18).

Esposito cenderung menyebut gerakan di kalangan Islam ini dengan istilah "Kebangkitan Islam" atau "aktivisme Islam" yang menurutnya tidak berat sebelah dan dianggap lebih sesuai dengan nilai-nilai dalam tradisi Islam. Nilai-nilai dan tradisi Islam yang dimaksud seperti konsep kebangkitan (tajdid) dan reformasi (islah) yang 
mencakup gagasan tentang aktivisme politik dan sosial, yang dimulai pada periode awal Islam sampai sekarang. Istilah ini digunakan supaya tidak dinilai sebagai generalisasi dari ajaran Kristen Protestan Amerika dan stereotip Barat (Esposito, 1994: 18).

Istilah tersebut hampir sama dengan yang dikemukakan oleh Roy, ia menyebut gerakan ini dengan sebutan "Islamisme". Merujuk pada pandangan yang berusaha melihat Islam sebagai ideologi yang tidak hanya diterapkan dalam wilayah politik, tapi juga pada segala dimensi kehidupan masyarakat modern (Roy, 2004: 58). Islam dalam pandangan seperti ini harus dipancarkan dalam segala bidang kehidupan masyarakat, mulai dari cara pemerintahan, pendidikan, sistem sosial, sistem hukum, sistem pertahanan dan keamanan, hingga kebudayaan dan ekonomi. Oleh karena itu, mereka melihat pentingnya sistem Islam dalam negara. Cara pandang demikian telah menjadikan Islam sebagai ideologi yang mengatur seluruh perangkat hidupnya. Berdasarkan Istilah tersebut, secara substansial pengertian Islam transnasional dapat disamakan artinya dengan istilah Islamisme.

Dalam konteks Indonesia, istilah Islam transnasional tidak diketahui secara pasti siapa yang memperkenalkan dan mempopulerkannya. Menariknya, wacana tersebut tidak dipopulerkan oleh kelompok yang berada dalam kategori gerakan Islam transnasional sendiri. Islam transnasional justru diperkenalkan dan dipopulerkan oleh kelompok Islam kultural. Kategorisasi Islam transnasional dan Islam kultural dalam dunia akademik atau dalam kajian ilmiah digunakan sebagai pisau analisis dalam membantu menjelaskan fenomena sosial tentang keragaman dari gerakan Islam yang berkembang di dunia muslim dewasa ini, khususnya di Indonesia.

Secara khusus di Indonesia, istilah Islam transnasional pertama kali disampaikan pada tahun 2007 oleh $\mathrm{KH}$ Hasyim Muzadi, seorang ulama dan mantan Ketua Umum Pengurus Besar Nahdlatul Ulama (PBNU). Istilah itu merujuk pada ideologi keagamaan lintas negara yang sengaja diimpor dari luar dan dikembangkan di Indonesia. Menariknya, ideologi ini menurut Hasyim Muzadi bukan hanya datang dari Timur Tengah, tapi juga dari Barat. Kelompok seperti Majelis Mujahidin, Ikhawanul Muslimin, Al-Qaedah disebut sebagai ideologi transnasional dari Timur, sedangkan Jaringan Islam Liberal sebagai kelompok yang mengembangkan ideologi transnasional dari Barat (NU Online, 29/04/2007).

Terminologi Islam transnasional juga diungkapkan oleh KH. Hasyim Muzadi untuk menggambarkan berbagai 
tipologi gerakan baru yang mulai menyebar di Indonesia yang di support oleh kekuatan di luar negeri. Lebih tepatnya Hasyim Muzadi ingin menyebutkan bahwa radikalisme yang terjadi di Indonesia terjadi karena dibantu oleh beberapa negara-negara maju, dan tidak murni keinginan orang Islam Indonesia. Istilah ini ditegaskan oleh KH. Hasyim Muzadi sebagai penegasian NU dari kelompok Islam yang bersifat transnasional (melintasi batasbatas nasionalisme keindonesiaan) maupun kelompok Islam yang membawa misi transformasi sosial-keagamaan secara radikal, ekstimis, fundamentalis dan tekstual (NU Online, 15/5/2007). Sebagai bentuk penegasian dirinya, PBNU meminta kepada bangsa Indonesia agar tidak mau mengikuti gerakan keagamaan yang berideologi transnasional (antar-negara). Pasalnya, kebanyakan gerakan dari ideologi tersebut tidak sesuai dengan kondisi masyarakat dan budaya setempat (NU Online, 15/5/2007). Selain gerakan ini tidak sesuai dengan budaya dan kultur Islam yang di kembangkan oleh $\mathrm{NU}$, gerakan ini juga dinilainya dapat mengancam sekaligus merusak Ideologi Pancasila dan NKRI.

Sumber lain menyebutkan bahwa Istilah transnasional dikemukakan oleh Ahmad Syafii Ma'arif mantan ketua umum Muhammadiyah. Ma'arif menyebut secara spesifik kepada HTI sebagai gerakan politik transnasional, ia menyoroti tentang HTI bahwa HTI, berbeda dengan MMI yang bercorak Indonesia, HTI adalah gerakan politik Islam Transnasional yang digagas oleh Taqiyuddin An-Nabhani. Namun, Ma'arif tidak menafsirkan organisasi apa saja yang dimaksudkan dalam kategori gerakan transnasional (Ma'arif, 2009: 191).

Gerakan transnasionalisme Islam yang dilakukan oleh Hizbut Tahrir sudah berwujud dan banyak ditemukan. Meskipun secara keilmiahan dalam dunia akademik terminologi tersebut beragam istilahnya. Selain itu, ada juga akademisi dan pengamat yang menyebut dengan istilah Islam radikal, Islam revivalis, Islam fundamentalis, Islam ekstrimis, Islam Normatif dan lain sebagainya. Meminjam istilah Fethullah Gulen Islam, melalui nilai universalismenya, Islam memang tidak bisa dimiliki oleh kalangan tertentu. Sebagai sebuah Negara yang bercorak Islam Syi'ah, Iran tentu memiliki tradisi sendiri dalam merayakan hari-hari besar Islam, terutama dalam merayakan tauladannya dan memperingati hari Asy-Syura. Sedangkan di negara lain, umat Islam juga punya tradisi lain yang mereka anggap sebagai bagian dari Islam. Begitu juga dengan Turki, yang dulunya dibangun di atas narasi sufisme Islam. 


\section{MUNCULNYA GERAKAN TRANSNASIONAL}

\begin{tabular}{lccr}
\multicolumn{1}{c}{ Munculnya } & \multicolumn{2}{c}{ Gerakan } & Islam \\
transnasional & tidak & terlepas & dari \\
kebangkitan & Islam & pada & masa
\end{tabular}

sebelumnya. Fenomena gerakan ini bisa ditarik ke belakang sejak kebangkitan dan pembaharuan Islam yang berkembang di Timur Tengah sejak abad ke-18. Beberapa gerakan Islam menandai era baru kebangkitan Islam di Timur Tengah antara lain: gerakan Muhammad bin Abdul Wahab (1703-1787) di Arabia bagian tengah yang melahirkan kelompok Wahabiyah. Selain itu, muncul juga gerakan pada abad ke-19 dan ke-20 yang dipimpin oleh tiga pemikir selanjutnya: Jamaludin al-Afghani (18391897) yang melahirkan gerakan Pan Islamisme, gerakan yang dipimpin oleh Muhammad Abduh (1849-1905), dan gerakan yang dipimpin oleh Rasyid Ridha (1865-1935) (Fealy dan Bubalo, 2007: 30).

Gerakan yang dikembangkan Muhammad bin Abdul Wahab yaitu gerakan untuk mengembalikan ajaran Islam sesuai dengan pemahaman as-salaf ash-shalih. As-salaf ash-shalih adalah tiga generasi pertama sahabat Nabi Muhammad SAW, pengikut generasi selanjutnya sering disebut sebagai gerakan Wahabiyah. Muhammad bin Abdul Wahab memusatkan gerakannya di Arabia bagian Tengah (Saudi Arabia).
Tujuan utama gerakan Wahabiyah yaitu memurnikan kembali ajaran Islam di tanah jazirah Arab yang dinilai telah terinfiltrasi dan mengalami akulturasi dengan budaya jahiliyah. Bangunanbangunan yang bernilai sejarah dan makam para sufi maupun makam tokohtokoh Islam banyak dihancurkan oleh gerakan Wahabi. Bangunan tersebut dinilai oleh mereka sebagai tempat bertaburnya tradisi-tradisi yang dapat merusak aqidah umat Islam. Dalam perkembangan selanjutnya, kehadiran Gerakan Wahabi membayang-bayangi lahirnya Ikhwanul Muslimin oleh Hassan Al-Banna di Mesir pada 1928. Pendiri gerakan ini berpandangan bahwa ancaman Barat terhadap umat Islam tidak hanya berbentuk fisik tapi juga non fisik. Ancaman yang berbentuk non fisik yaitu munculnya kaum intelektual yang rasional-empiris. Umumnya, kelompok ini cenderung mengesampingkan sisi-sisi spiritualitas Islam. Cara melawannya yaitu dengan kembali pada dasar-dasar Islam, dan perlunya pola perilaku hidup Islam serta sistem Islam dalam negara.

Setelah kematian Hasan Al-Banna akhir tahun 1950-an, gagasan ideologi Ikhwanul Muslimin selanjutnya dikembangkan oleh Sayyid Qutb. Sayyid Qutb memulai gerakannya dengan menghasut umat Islam di Mesir untuk melawan Pemerintah. Karena tulisan dan pemikirannya di anggap berbahaya, 
tahun 1966 ia dieksekusi oleh pemerintah di bawah pimpinan Jamal Abdul Nasser, Presiden Mesir waktu itu. Setelah kebijakan represif mulai diberlakukan oleh pemerintah Mesir, sebagian aktivis Ikhwanul Muslimin mengungsi ke beberapa negara tetangga yang dianggap aman, termasuk Arab Saudi. Salah satu aktivis yang mengungsi ke Arab Saudi adalah Said Ramadhan yang kemudian menjadi salah seorang pendiri Rabithah al-Alam Islami. Menantu al-Banna ini kemudian pindah ke Jenewa untuk mengembangkan pemikiran dan ideologi Ikhwanul Muslimin di kawasan Eropa.

Muhammad Qutb, adik kandung dari Sayyid Qutb, juga ikut pindah ke Arab Saudi untuk menyelamatkan diri. Selama di Arab Saudi, ia menjadi dosen di King Abdul Aziz University Jeddah. Di kampus inilah Muhammad Qutb menanamkan pemikirannya kepada mahasiswa dari berbagai Negara, salah satunya adalah Osama bin Laden (Wahid (ed), 2009: 82). Osama bin Laden inilah yang membuka gagasan dan ideologi Ikhwanul Muslimin yang bermetamorfosis menjadi gerakan yang lebih ekstrim. Jaringan gerakan selanjutnya menyebar di berbagai negara, termasuk di Indonesia melalui Abu Bakar Ba'asyir. Abu Bakar Ba'asyir seorang asli Indonesia yang menjadi tokoh sentral gerakan Islam radikal di Indonesia. Sekarang ia menjadi Amir
Majelis Mujahiddin Indonesia (MMI) dan pimpinan utama dari Jamaah Anshorut Tauhid (JAT).

Beberapa teori yang membahas tentang munculnya Gerakan Islam transnasional di dunia Islam antara lain. Pertama, adanya kegagalan umat Islam dalam menghadapi arus modernitas yang dinilai telah menyudutkan Islam. Kedua, adanya rasa kesetiakawanan terhadap nasib yang menimpa saudara-saudara seagamanya seperti yang terjadi di Palestina, Kashmir, Afganistan dan Irak. Perasaan solidaritas ini sesungguhnya dimiliki oleh seluruh umat Islam sedunia. Namun, cara meresponnya berbeda dengan mayoritas muslim lainnya. Ketiga, secara khusus di Indonesia, maraknya fundamentalisme lebih disebabkan oleh kegagalan negara dalam mewujudkan cita-cita kemerdekaan berupa tegaknya keadilan sosial dan terciptanya kesejahteraan yang merata bagi seluruh rakyat. (Wahid, 2009: 8-9). Wahid dalam melihat infiltrasi gerakan Islam transnasional di Indonesia, cenderung mengkategorikannya sebagai gerakan Islam fundamentalis.

Munculnya modernitas dianggap sebagai salah satu penyebab kegagalan umat Islam. Di tengah ketidakberdayaan menghadapi arus modernitas, golongan fundamentalis mencari dalil-dalil agama untuk "menghibur," dalam sebuah dunia yang dibayangkan belum tercemar. Jika 
sekedar "menghibur" barang kali tidak akan menimbulkan banyak masalah (Wahid, 2009: 8). Masalah akan muncul saat mereka mulai menyusun kekuatan politik dalam melawan arus modernitas, sehingga kepentingan mereka akan berbenturan dengan golongan Islam yang lain yang tidak setuju dengan cara yang mereka lakukan.

Munculnya ideologi kapitalisme, nasionalisme, sekulerisme, pluralisme, liberalisme serta sistem demokrasi telah memberikan warna tersendiri di tengah kehidupan umat manusia. Bagi mereka, kehadiran ideologi/gagasan tersebut dianggap sebagai virus yang akan mencemari akidah umat Islam. Dalam usaha untuk membendung tantangan modernitas, kelompok Islam ini mencari dalil-dalil agama yang dapat dijadikan alasan untuk melegitimasi kebenaran yang akan disampaikan. Kebenaran ini bagi mereka adalah murni datangnya dari Tuhan berdasarkan kitab suci AlQur'an dan Sunnah Rasul Muhammad SAW. Meskipun teks-teks yang mereka baca banyak kalangan menganggap bahwa pemahaman mereka cenderung bersifat tekstual, rigit dan kaku.

Hizbut Tahrir sebagai manifestasi dari Islam trasnasional, memandang modernitas sebagai sumber kegagalan umat Islam. Isme-isme yang muncul sebagai produk modernitas termasuk sistem demokrasi yang berlaku dianggap sebagai sistem yang kufur, sehingga haram bagi mereka untuk mempelajari, menerima dan menerapkannya.

Gerakan islam transnasional juga muncul karena adanya rasa kesetiakawanan atau sifat solidaritas terhadap umat Islam seperti di Irak, Afganistan dan Pakistan atas nasib di daerahnya akibat penjajahan yang dilakukan oleh negara-negara lain. Transnasionalisme Islam di Timur Tengah bagi mereka dianggap sebagai langkah efektif dalam membebaskan dirinya dari imperialisme dan kolonialisme bangsa Barat.

Sesungguhnya sikap solidaritas ini telah berlaku umum dan dimiliki oleh seluruh umat Islam, sebagai pengejewantahan dari rasa persaudaraan sesama Islam (Ukhuwah Islamiyah) di dunia Islam. Namun, hal yang membedakan adalah sikap yang ditunjukkan oleh golongan mayoritas yang sejauh mungkin menghindari kekerasan dan tetap mengibarkan panjipanji perdamaian, sekalipun penderitaan umat Islam di daerah konflik itu sering tidak tertahankan lagi (Wahid, 2009: 9). Bagi mereka, agar umat Islam bisa bersatu, mendirikan negara Islam di tengah penjajahan yang menimpa umat Islam di Temur Tengah menjadi sebuah kewajiban yang harus ditegakkan. Langkah ini sekaligus menyatukan kembali negara-negara yang terpecah 
sebagai akibat dari konspirasi barat dalam meruntuhkan Islam pada masa Turki Usmani.

Pasca runtuhnya kekhilafahan Islam yang berpusat di Turki (Turki Usmani) pada 1924, dominasi Barat terhadap negara-negara yang pernah menjadi bagian dari wilayah kekuasaan Turki Usmani mulai dirasakan. Ideologi Kapitalisme, Imperialisme dan Kolonialisme mulai menancapkam kakinya di wilayah tersebut. Dalam kondisi demikian, umat Islam di Timur Tengah juga membangun kembali kekuatan-kekuatan baru guna melakukan perlawanan terhadap kolonialisme bangsa-bangsa Barat di daerahnya masing-masing. Dalam suasana dan kondisi yang mencekam umat Islam tersebut, Taqiyuddin AnNabhani, mendirikan Hizbut Tahrir (HT) yang di Kota Haifa, Palestina. Tujuan didirikan HT yaitu untuk menyatukan kembali Umat Islam di bawah satu sistem pemerintahan (khilafah Islamiyah).

Pembentukan HT nampaknya merupakan respon An- Nabhani terhadap kolonialisme Barat yang mengakibatkan jatuhnya kekhilafahan Islam, serta terpecahnya negara-negara muslim Arab ke dalam sejumlah negara bangsa. Oleh karena itu, perhatian utamanya adalah menyatukan negaranegara muslim Arab di bawah satu sistem pemerintahan. An-Nabhani selalu menunjukan keinginan yang kuat untuk membebaskan umat Islam dari cengkeraman imperialisme Barat. Dalam bukunya, Mafahim Hizbut Tahrir, ia menjelaskan bahwa HT menentang penjajahan dalam segalah bentuk dalam istilahnya. HT juga membebaskan umat dari qiyadah fikriyah, penjajah, dan mencabut dari akar-akarnya; baik aspek budaya, politik, militer, ekonomi dan sebagainya dari tanah negeri kaum muslim. HT juga berjuang mengubah ideide (Mafahim) yang telah tercemari oleh penjajah, yang membatasi Islam hanya pada aspek ibadah dan akhlak semata." (An-Nabhani, 2007: 128).

Selain HT, setidaknya ada empat gerakan Islam awal yang muncul sebagai ikon perlawanan umat Islam atas kolonialisme Barat. Pertama, Pan Islamisme yang didirikan oleh Jamaluddin Al-Afgani. Kedua, Ikhwanul Muslimin yang didirikan oleh Hasan AlBanna di Mesir. Ketiga, Al-Jami'at AlIslamiyah di Pakistan. Keempat, Gerakan Wahabiyah yang di konstruk oleh Muhammad bin Abdul Wahab dalam melakukan gerakan purifikasi keislaman di Jazirah Arab. Selain itu, Revolusi Islam Iran yang di pimpin oleh Imam Khomeini juga berpengaruh dalam gerakan Islam di berbagai negara akhir-akhir ini. Dengan semangat yang dibangun di atas spritualitas Islam Syi'ah-nya, masyarakat mampu menjatuhkan Syah Pahlevi 
(Presiden Iran) yang dianggap sebagai kaki tangan bangsa asing dan dinilai sebagai rezim diktator terhadap masyarakatnya.

\section{PENGARUH GERAKAN ISLAM TRANSNASIONAL DI INDONESIA}

Hubungan umat Islam Nusantara dengan umat Islam di Timur Tengah, telah melahirkan banyak ulama-ulama di Nusantara. Umat Islam Nusantara banyak yang belajar mendalami agama Islam dari Ulama di Timur Timur. Setelah mereka belajar berbagai keahlian dan bidang ilmu di sana, ulama-ulama kembali ke Nusantara untuk menyebarkan dan mengembangkan ilmu yang telah di pelajarinya. Bersamaan dengan itu, Revivalisme Islam di Timur Tengah telah membawa pengaruhnya di Indonesia sudah dimulai sejak abad ke17. Hadirnya organisasi kemasyarakatan Islam seperti Muhammadiyah pada 1912, dan Nahdlatul Ulama pada 1924, tidak bisa dilepaskan dari pengaruh revivalisme Islam di Timur Tengah ini. Kedua tokoh pendiri ormas ini (KH. Ahmad Dahlan dan KH. Hasyim Asyari) sama-sama mendalami ilmu agama di Timur Tengah. Selama beberapa abad, sejarah mencatat banyak orang Indonesia pergi ke Timur Tengah baik sebagai haji, pedagang, pelajar, maupun sebagai ulama.
Banyak Kalangan pelajar atau mahasiswa yang belajar di Timur Tengah setelah kembali ke Indonesia, mereka mulai menyebarkan ide-ide/gagasan di kalangan umat Islam Indonesia dengan beragam pemikiran yang berbada-beda. Mereka mengembangkan ide-idenya di kalangan generasi muslim masyarakat kota, pelajar maupun mahasiswa. Di kampus-kampus terdapat beberapa organisasi kerohanian, Lembaga Dakwah Kampus (LDK) dan Masjid/Mosholah dijadikan sebagai sarana untuk mentransformasikan pemikiran dan gagasannya.

Transnasionalisme Islam atau Islamisme dalam pengertian yang dimaksud disini adalah pengaruh Islamisme Timur Tengah di Indonesia. Gerakan ini sebagaimana dikemukakan dalam studi Fealy dan Bubalo adalah penegasannya untuk tidak melihat gerakan transnasional ini sebagai gerakan yang monolitik. Melihat Islamisme yang dikembangkan di Timur Tengah hanya sekadar gerakan yang radikal, ekstrim, bukan hanya melahirkan sikap permusuhan baru tapi juga bisa mengabaikan pada gradasi Islamisme yang lebih moderat. Meskipun pada dasarnya tetap bermasalah bagi penguatan negara Indonesia. Gerakangerakan mempromosikan sejumlah perda syariat di banyak daerah di Indonesia adalah strategi yang jauh lebih 
moderat bahkan terkesan demokratis adalah salah satu varian strategi gerakan transnasional ini. Studi keduanya berusaha memberi gambaran yang lebih bervariasi baik ketika menjelaskan jalur pengaruh Timur Tengah atas Indonesia, maupun ketika mengategorikan kelompok-kelompok Islamis ini. Jalur transmisi ide-ide Islamisme itu menurut studi ini setidaknya mengambil tiga jalur (Fealy dan Bubalo, 1996: 84).

Pertama, gerakan-gerakan sosial. Di jalur ini transmisi ide dibawa oleh pelajar atau mahasiswa yang belajar di Timur Tengah. Mereka belajar di Universitas Al-Azhar Kairo, Universitas Islam Madinah, Universitas Umul Qura Mekah, Universitas al-Imam Muhammad bin Saud di Riyadh, atau Universitas King Abdul Aziz. Sementara itu, saluran utama kelompok jihadis adalah melalui perang Afghanistan pada 1980-an yang kemudian melahirkan kelompok AlQaeda dan Jamaah Islamiyah (Fealy dan Bubalo, 2007: 89-90).

Kedua, jalur pendidikan dan dakwah. Lembaga-lembaga dan beberapa orang dari negara Timur Tengah seperti Arab Saudi, UEA Mesir dan Kuwait belakangan cukup aktif berkiprah di bidang pendidikan dan dakwah di Indonesia. Agen-agen itu meliputi atase kedutaan Arab Saudi di Jakarta, Rabithah Alam Islami, International Islamic Relief Organization (IIRO) dan Word Assembly
Muslim Youth (WAMY), atau lembaga amal non pemerintah seperti AlHaramain yang cabangnya di Indonesia dituding Amerika sebagai organisai pendukung terorisme. Lembaga Ilmu Pengetahuan Islam dan Arab (LIPIA) Cabang Universitas al-Imam Muhammad bin Saud di Riyadh, Arab Saudi juga dianggap salah satu lembaga yang mentransmisikan ide-ide Ikhawanul Muslimin dan salafi. Sebagian alumninya ada yang menjadi petinggi PKS. Penelitian Sidney Jones menyebut sebagian besar para alumni menjadi figur berpengaruh dalam gerakan salafi di Indonesia melalui penerbitan, atau dengan menjadi dai, guru maupun ulama. (Fealy, 1996: 92-96). Tiga organisasi yang secara khusus mendapat dukungan signifikan dari Arab Saudi akhir-akhir ini adalah Dewan Dakwah Islamiyah Indonesia (DDII), Jamaah Islam wa alIrsyad (JII) dan Persis.

Ketiga, jalur publikasi dan internet. Melalui sejumlah media baik cetak maupun online, atau buku-buku dalam versi Arab maupun terjemahan, juga menjadi salah satu jalur transmisi cukup efektif. Beberapa penerbit buku di Indonesia bahkan mengkhususkan, menerbitkan atau menerjemahakan buku beraliran salafi dan pemikiran-pemikiran dari kalangan Ikhwanul Muslimin (Fealy dan Bubalo, 2007: 101-104). 
Studi Fealy dan Bubalo selanjutnya menyebut tiga arus utama gerakan Islamisme yang ada di Tanah Air. Pertama, Ikhawanul Muslimin yang diadopsi gerakan tarbiyah dan mulai berkembang di perguruan tinggi di akhir tahun 1980-an dan awal tahun 1990-an. Gerakan kelompok ini berkembang underground di bawah tekanan rezim Soeharto. Konsolidasi ini menemukan momentumnya ketika rezim Soeharto berakhir. Kesatuan Aksi Mahasiswa Muslim Indonesia yang berdiri pada April 1998, sebagian pemimpinnya kemudian mendirikan Partai Keadilan Sejahtera (waktu itu bernama Partai Keadilan). Kedua, kelompok salafi. Kelompok ini sebagian besar berbasis lembaga dakwah dan pendidikan. Misalnya Yayasan al-Sofwah, Yayasan Ihsa at-Turost, dan Al-Haramain alKhoiriyah, dan lain-lain. Gerakan salafi yang cukup fenomenal adalah Forum Komunikasi Ahlus Sunnah Waljamaah (FKAWJ) yang melahirkan Laskar Jihad pimpinan Jafar Umar Tholib. FKAWJ Berdiri 1998, dan dibubarkan pada bulan Oktober 2002. Ketiga, kelompok jihadis. Kelompok ini adalah kelompok yang paling ekstrem dari gerakan islamisme yang mengesahkan kekerasan seperti bom bunuh diri. Selain itu, ada juga kelompok yang didirikan pada 1 Januari 1993 oleh Abdullah Sungkar termasuk kelompok Jihadi. Jejaring inilah yang kemudian melakukan aksi-aksi bom bunuh diri seperti yang dilakukan Imam Samudera dan kawan-kawan (Fealy dan Bubalo, 2007: 106-138).

\section{PENUTUP}

Gerakan Islam Transnasional sebagai nomenklatur adalah pergerakan Islam dengan kelembagaan memiliki jejaring internasional serta adanya agenda penyatuan umat Islam. Meskipun secara keilmiahan dalam dunia akademik terminologi tersebut beragam istilahnya, diantaranya ada yang menyebut Deteritorialisasi Islam, Islam radikal, Islam revivalis, Islam fundamentalis, Islam ekstrimis, Islam normatif, maupun istilah-istilah yang lainnya. Namun, secara umum terdapat kesamaan dalam mengusung ideologi tunggal sebagai citacita bersama.

Sejarah kehadiran gerakan Islam transnasional merupakan bagian dari gerakan pembaharuan pada abad ke-18 di Timur Tengah yang dikemukakan oleh Muhammad Bin Abdul Wahab yang dilanjutkan oleh tiga generasinya pada abad ke-19 sampai abad ke-20. Corak gerakan Islam transnasional telah menemukan momentum yang tepat pasca runtuhnya kekhalifahan Islam yang berpusat di Turki Usmani tahun 1924. Beragam organisasi mulai muncul seperti Pan Islamisme yang dipimpin oleh Jamaluddin al-Afgani, Ikhwanul 
Muslimin oleh Syaikh Hasan al-Banna, Hizbut Tahrir oleh Syaikh Taqiyuddin anNabhani, Jamiah al-Islamiyah oleh Sayyid Qutb, Wahabiyah di Arab Saudi, Salafi Jihadis di Irak dan Afganistan dan Syi'ah yang berkembang di Iran.

Pemikiran dari gerakan-gerakan Islam tersebut telah ikut mempengaruhi kelompok gerakan keislaman di Indonesia. Jalur-jalur yang digunakan dalam transmisi ide-ide dan gerakannya melalui jalur gerakan sosial, jalur dakwah dan dunia pendidikan serta jalur media dan publikasi. Dengan demikian, kehadirannya memberikan warna dan tantangan tersendiri bagi gerakan Islam, khususnya di Indonesia.

\section{REFERENSI}

An-Nabhani, T. 2007. Mafahim Hizbut Tahrir (terj). Jakarta: HTI Press.

Esposito, J. L. 1994. Ancaman Islam Mitos atau Realitas (terj). cetakan III (edisi revisi).Bandung: Mizan

_. 2004. Islam Warna-Warni: Ragam Ekspresi Menuju Jalan Lurus (al-sirat al-mustaqim). Alih Bahasa Arif Maftuhin. Jakarta: Paramadina.

Fealy, Greg. dan Bubalo, Antony. 2007. Jejak Kafilah: Pengaruh Radikalisme Timur Tengah di Indonesia (terj). Bandung: Mizan.

Hilmy, M. 2011. Akar-Akar Transnasionalisme Islam Hizbut Tahrir Indonesia (HTI). Jurnal Islamica, Vol. 6, No.1.
Ma'arif, A. S. 2009. Islam dalam Bingkai Keindonesiaan dan Kemanusiaan: Sebuah Refreksi Sejarah. Bandung: Mizan.

Roy, 0. 2004. Gagalnya Islam Politik. Alih bahasa Harimurti dan Qomaruddin SF. Jakarta: Serambi

Wahid, A. (ed). 2009. Ilusi Negara Islam: Ekspansi Gerakan Islam Transnasional di Indonesia. Jakarta: Gerakan Bhinneka Tunggal Ika-the Wahid Institute-the Maarif Institute. 